\title{
Distress, Anxiety and Depression in Patients Who Have Received Hematologic Cancer Diagnosis
}

\section{Hematolojik Kanserli Hastaların Anksiyete, Depresyon ve Distres Yaşama Durumları}

\author{
Elif Çalışkan ${ }^{1}$, Nermin Gürhan ${ }^{2}$, Ali İrfan Emre Tekgündüz ${ }^{1}$
}

${ }^{1}$ Dr. Abdurrahman Yurtarslan Ankara Onkoloji Eğitim Ve Araştırma Hastanesi, Hematoloji Departmanı

${ }^{2}$ Gazi Üniversitesi Sağlık Bilimleri Fakültesi

Dergiye Ulașma Tarihi: 05.03.2017 Dergiye Kabul Tarihi: 27.03.2017 Doi: 10.5505/aot.2017.70298

\section{ÖZET}

GİRIŞ ve AMAÇ: Bu çalışmanın amacı, hematolojik kanser tanısı almış ve kemoterapi tedavisi görmekte olan hastalarda distres, anksiyete ve depresyon yaşama durumlarını belirlemektir. YÖNTEM ve GEREÇLER: Tanımlayıcı kesitsel tipte yapılan çalışmanın örneklemini, hematolojik kanser tanısı almış, hematoloji servisine yatıșı yapılan veya ayaktan kemoterapi tedavisi görmekte olan 75 bireyden oluşmaktadır. Hastalara kişisel bilgi formu, Distres Termometresi (DT) ve Hastane Anksiyete ve Depresyon
Skalas1
(HADS)
testleri
uyguland1.

BULGULAR: DT'ye göre 52 hastanın $(\% 69,3)$ yüksek stres $(\geq 4)$ yaşadığ 1,23 hastanın $(\% 30,7)$ düşük stres $(<4)$ yaşadığı belirlenmiştir. HAD ölçeğine göre, HAD-Anksiyete alt boyutu açısından 17 hastanın (\%22,7) 10 ve üzeri olduğu belirlenmiştir. HAD-Depresyon alt boyutu açısından 47 hastanın $(\% 62,7) 7$ ve üzeri olduğu belirlenmiştir. DT ve HAD skalaları arasında pozitif yönlü korelasyon vardır. Bayanların anksiyete puan ortalamasının, erkeklerin anksiyete puan ortalamasından istatistiksel olarak anlamlı düzeyde daha yüksek olduğu belirlenmiştir. TARTIŞMA ve SONUÇ: Hastaların büyük çoğunluğu tanı anından itibaren tedavi süreci boyunca distres yaşamaktadır. Hastaların distresi artıkça anksiyete ve depresyon seviyeleri de artmaktadır. Böylece hastaların fiziksel ve emosyonel yakınmaları artarken, tedaviye uyum zorlaşmakta, hastane yatış süreleri artmakta ve hastanın yaşam kalitesi azalmaktadır. Psikolojik sıkıntı yaşayan hastaların gözden kaçmaması, tespit edilmesi ve yönlendirilmesi için ve nicel olarak ölçüm yapan, zaman almayan tarama ölçekleriyle hastaların rutin olarak değerlendirilmesi literatür ışığında önerilmektedir.

Anahtar Kelimeler: Hematolojik Kanser, Distres, Anksiyete ve Depresyon

\section{ABSTRACT}

INTRODUCTION: The aim of this study is to determine distress, anxiety and depression in patients who have received hematologic cancer diagnosis and who are on chemotherapy treatment. METHODS: The sample consisted of 75 individuals who were diagnosed with hematologic cancer and who were on chemotherapy treatment in the hematology department and in there mote chemotherapy unit. Participant were applied personal information form, Distress Thermometer (DT) and Hospital Anxiety and Depression Scale (HADS).

RESULTS: According to DT, 52 patients (69.3\%) had highstress ( $\geq 4), 23$ patients $(30.7 \%)$ had lowstress $(<4)$. According to the HAD scale, HAD-Anxiety sub-dimension was found to be over 10 in 17 patients $(22.7 \%)$. In terms of HAD-Depression sub-dimension, it was determined that 47 patients $(62.7 \%)$ wereover 7 . There is a significant positive difference between DT and HAD scales. Theme an anxiety score of the ladies was found to be statistically higher than the average of the anxiety scores of the males. DISCUSSION AND CONCLUSION: The vast majority of patient sare distressed during the treatment process from the time of diagnosis. Anxiety and depression levels increase as patients' distress increases. Thus, the physical and emotional complaints of the patient sare increased, the compliance with the treatment becomes difficult, the length of hospital stay increases and the quality of life of the patient decreases. Patients should be screened routinely with easy screening scales to detect patients suffering from psychological distress.

Keywords: Heamatological cancer, Distress, Anxiety and Depression 


\section{GIRIŞ}

Kanser, tanı aşamasından terminal döneme dek, bireyin biyo-pisiko-sosyal tüm yaşantısını derinden etkilemektedir. Kişi kanser tanıs1 alması ile beraber kanser tanısının varlığı, kanser tedavisinin zorluğu, tedavinin yan etkileri, bilinmezlik korkusu, hastalık gerilese bile tekrar hastalığın nüks etme korkusu ve ölüm korkusu kişinin tüm yaşam dengesini değiştirmekte ve psikolojik sıkıntılar yaşamasına neden olmaktadır. Kanser sadece fiziksel bir hastalık değil ruhsal açıdan da bireyi etkileyen bir olgudur (Karakaş, 2007; Çapar, 2010).

Kanser tedavi sürecinde s1klıkla görülen azalmış sosyal işlevsellik, fiziksel ve bilişsel bozuklukların artması, somatik semptomların artması, kanserin nüksetme ihtimali, tedavinin işe yaramayacağı korkusu emosyonel distresle ilişkilidir (Boyes ve ark. 2013). "Distres" terimi NCCN (Ulusal Kapsamlı Kanser A $\breve{g}_{1}$ ) tarafindan tanımlanmış bir terimdir(NCCN, 2016). Distres, kanserle baş etme yetisini engelleyen, hoş olmayan hisleri ve duyguları, bunların fiziksel belirtilerini ve ele alınış şeklini tanımlamak için kullanılmaktadir(Bultz ve Carlson 2005).Distres terimi, kanser hastaları için daha az damgalayıcı bir terimdir ve hastaların kendini daha rahat ifade etmesini sağlar (NCCN, 2016).Psikolojik distresin saptanmasının ve tedavi edilmesinin kritik önemine rağmen sağl1k hizmeti verenler distres yaşayan hastaları saptamakta başarısızdırlar(Rankin ve ark. 2011). Çoğu kanser hastasının bakımında sadece sikıntılı hastalara psikososyal bakım verildiği ve kanserli hastaların çoğunun psikososyal konulardaki yardım ihtiyaçlarının karşılanmadığg belirtilmektedir (Harison ve ark 2009). Oysa kanser süreci boyunca hastaların distres açısından da taranması gerektiği kaçınılmaz bir gerçektir. 2005'de Canadian Strategy for Cancer Control, distress ölçümünü nabız, tansiyon, solunum gibi rutin olarak ölçülmesi gereken bir vital bulgu olarak tanımlamıştır (Bultz ve Holland 2005).

Anksiyete, her bireyin yaşamı boyunca belirli dönemlerde yaşayabildiği, genellikle bilinmeyen ve anlaşılamayan huzursuzluk ve gerginlik hissi olarak tanımlanır. D1ş uyaranlarla organizmanın dengesini bozan stres ise anksiyete ile iç içe bir olgudur. Kişi için ruhsal dengesini tehdit eden bir stresöranksiyeteye, anksiyete ise ruhsal dengesini tehdit eden bir stresör gibi etki oluşturarak strese neden olabilmektedir (Öz, 2004). Kanser hastalarında anksiyete ve depresyonun, ruhsal açıdan hastaya zarar verdiği ve hastalığın prognozununu negatif yönde etkilediği(Giraldi ve ark, 2007), Nalepa'nın (1996) yaptı̆̆ dakemoterapi alan kanser hastalarında anksiyete ve depresyon siklığının oldukça yüksek olduğu bildirilmiştir.

Ülkemizde pek çok alanda olduğu gibi hematolojik maligniteler konusunda da düzenli istatistiksel veriler bulunmamaktadir. Kulaksızoğlu ve ark (1999) yaptığı bir araştırmada; hematolojik kanseri bulunan geniş bir hasta grubunda ortaya çıkan psikiyatrik hastalıkların sıklığı ve dağılımının geriye dönük olarak belirlenmesi amaçlanmıştır. Hastaların $\% 35,9$ 'u akut miyeloblastik lösemi, \%25,4'ü akut lenfoblastik lösemi, \%15,5'i kronik miyelositer lösemi, \%8,7'si multiplmiyeloma tanıs1 ile tedavi görmektedir. Psikiyatrik tanıların dağılımlarında ise, \%30,3'üne herhangi bir majör psikiyatrik bozukluk tanıs1 konmadığı, en sik görülen psikiyatrik bozukluğun uyum bozukluğu $(\% 40,3)$ olduğu, bunumajör depresyon $(\% 11,5)$, anksiyete bozuklukları $(\% 5,9)$ ve deliryum $(\% 5,6)$ tanılarının izlediği gözlenmiştir.

$\begin{array}{ccr}\text { Hematolojik } & \text { kanserlerin } & \text { tedavi } \\ \text { sirasinda hastaların } & \% 35 \text { 'inde yüksek }\end{array}$ düzeylerde anksiyete ve depresyon geliştiği ve tedavi boyunca da anksiyete ve depresyon geliştiği bildirilmiştir (Andrykowski ve ark, 1995). Hematolojik kanserlerde depresyonun göreceli olarak s1k görülmesi ve klinik olarak eşlik eden bir hastalık olmasına rağmen bu hastalardaki anksiyete ve depresyona gösterilen tıbbi ilgi oldukça yetersizdir (Karahan, 2011).

Yapılan çalışmada,hematolojik kanserli hastalarda anksiyete, depresyon ve distres yaşama durumlarını incelemek ve araştırma bulgularının 1şığında sağlık personeli 
aydınlatılacak ve hastanın fiziksel ihtiyaçlarının yanı sıra psikolojik ihtiyaçlarının da sağlanmasına yardımcı olunacaktır.

\section{GEREÇ VE YÖNTEM}

\subsection{Araştırmanın Evreni ve Örneklem}

Araştırmanın evrenini, Dr. Abdurrahman Yurtarslan Ankara Onkoloji Eğitim ve Araştırma Hastanesi hematoloji servisine yatışı yapılan ve ayaktan kemoterapi ünitesinde hematolojik kanser tanısı almış ve kemoterapi tedavisi görmekte olan bireyler oluşturmaktadır.

Araştırma tanımlayıcı kesitsel tiptedir. Örneklemi, Mayıs 2016-Eylül 2016 tarihleri arasında serviste yatmış ve ayaktan kemoterapi ünitesinde kemoterapi tedavisi görmüş 75 hasta oluşturmaktadır. Genel durumu bozuk olan, bilinci yerinde olmayan ve çalışmaya katılmayı kabul etmeyen hastalar örnekleme alınmamıştır.

\section{Veriler}

"Statistical

PackagefortheSocialSciences (SPSS) for Windows 22.0" istatistik programında değerlendirilmiştir.

Veriler değerlendirilirken tanımlayıcı istatistiksel metotların (yüzdelik, ortalama, standart sapma) yanı sıra, parametrik dağılıma sahip olan yöntemler için iki bağımsız grup karşılaştırmasında Independent-Sample $\mathrm{t}$ test ( $\mathrm{t}$ değeri); üç veya daha fazla bağımsız grup için ANOVA (F değeri) ve bazı tablolarda Pearson korelasyon katsayıs1 yöntemi kullanılmıştır.

\subsection{Veri Toplama Formları}

Hasta Bilgi Formu:Araştırmaya katılacak gönüllülerin yaş, cinsiyet, gelir durumu, eğitim durumu, tanısı, klinik evresi, tedavi süresi ve hastalığa uyumunu belirleyecek sorular vardır.Kişisel Bilgi Formu, hastaların bazı sosyo-demografik ve tıbbi özellikler, hastalık ve tedaviye ilişkin özelliklerini belirlemek amacıyla konu ile ilgili literatür taraması sonucunda oluşturulmuştur.

Hastane Anksiyete ve Depresyon Ölçeği (HADS): Hastada anksiyete ve depresyon yönünden riski belirlemek, anksiyete düzeyini ölçmek amaciyla Zigmond ve Snaith tarafından geliştirilen, dörtlü likert tipi bir ölçektir. Toplam 14 soru içermekte ve tek sayılar anksiyeteyi, çift sayılar depresyonu ölçmektedir. Formun Türkçe geçerlik ve güvenirliği Aydemir tarafindan yapılmış, ölçeğin bedensel hastalığ olanlarda depresyon ve anksiyete belirtilerini tarama açısından güvenli olduğu belirlenmiştir. Ölçeğin, anksiyete (HAD-A) ve depresyon (HAD-D) alt ölçekleri vardır. Anksiyete alt ölçeği için kesme puanı 10/11, depresyon alt ölçeği için ise $7 / 8$ bulunmuştur. Buna göre bu puanların üzerinde alanlar risk altında olarak değerlendirilirler. Ölçekte her maddenin puanlaması farklıdır. 1., 3., 5., 6., 8., 10., 11. ve 13. maddeler giderek azalan şiddet gösterirler ve puanlama $3,2,1,0$ biçimindedir. Öte yandan 2., 4., 7., 9., 12. ve 14. maddeler ise $0,1,2,3$, biçiminde puanlanırlar. Anksiyete alt ölçeği için 1., 3., 5., 7., 9., 11. ve 13. maddelerin puanlar1 toplanırken; depresyon alt ölçeği için 2., 4., 6., 8., 10., 12. ve 14. maddelerinin puanlar1 toplanır. Hastaların ve bakım verenlerin her iki alt ölçekten alabilecekleri en düşük puan 0, en yüksek puan 21'dir (Aydemir 1997)

\section{Distres Termometresi (DT):}

Kanser hastalarında psikososyal distresi ölçmek için Roth ve ark. tarafından 1998 yılında geliştirilen bir ölçektir. Distress seviyesi termometre analojisi ile 010 arasında derecelendirilmiştir. Bireylerin kendi kendilerine uygulayabilecekleri, yalnızca bir sorudan oluşan görsel analog bir skaladır. Ölçeğin üzerinde 0 'dan 10'a 
kadar rakamlar olan bir termometre bulunmaktadır. Uygulayıcı yaşadığı distresi bu termometre üzerindeki rakamlar aracılığıyla ifade etmektedir. 0 puan bireyin hiç distres yaşamadığını, 10 puan ise en üst sınırda distres yaşadığını göstermektedir. DT'nin ülkemizdeki geçerlilik güvenilirlik çalışması, Özalp ve ark. tarafından 2006 yılında yapılmıştır. Çalışmada ölçeğin duyarlılığı $\quad 0.73, \quad$ özgüllüğü $\quad 0,49$ bulunmuştur30. $\mathrm{Bu}$ nedenle bu çalışmada da bu ölçek kullanılmıştır. Özalp ve arkadaşlarının yaptığı çalışmada ölçeğin ülkemizdeki kesim noktası 4 bulunmuştur.

2003 y1linda NCCN, distres termometresine problem listesini eklemiştir. Problem listesi, kanser hastalarında sıklıkla görülen sorunlardan oluşmaktadır. Hastalar listede olan sorunlardan hangisinin ya da hangilerinin, geçen bir hafta içinde kendisine sıkıntı yaşattığını işaretlemektedir. Listedeki sorunlar 5 ayrı grupta toplanmıştır. Birinci grup günlük yaşam sorunlarından oluşmaktadır. Bunlar; barınma, sosyal güvence, iş/okul, ulaşım, çocuk bakımı olarak sıralanmıştır. İkinci grupta ailevi sorunlar yer almaktadır. Eş ve çocuklar bu grubu oluşturmaktadır. Üçüncü grup duygusal sorunları içermekte, üzüntü, hüzün, depresyon ve sinirlilikten oluşmaktadır. Dördüncü grupta inançla ilgili sorunlara yer verilmiş, tanrı ile ilgili, inanç yitimi, diğer sorunlar ele alınmıştır. Beşinci ve son grup ise bedensel sorunlardan oluşmaktadır. Bedensel sorunlar içinde yer alan durumlar ise; ağrı, bulant1, yorgunluk, uyku, gezinti, banyo yapma/giyinme, nefes darlığı, ağız yaraları, yemek yeme, hazımsızlık, kabızlık/ishal, idrar sorunları, ateş, ciltte kuruma/kaşıntı, burun tıkanıklığ 1 , el/ayakta karıncalanma, şişkinlik hissi ve cinsel sorunlardır. (Özalp 2007, Roth 1998, Özbaş 2008)

\subsection{Araștırmanın Etik Yönü:}

Dr. Abdurrahman Yurtaslan Ankara Onkoloji Hastanesi Etik Kurulu'ndan ve Dr.
Abdurrahman Yurtaslan Ankara Onkoloji Hastanesi HematolojiBilimdalı'ndan yazılı izin ve araștırmaya katılan hastalardan yazılı onam alınmıştır. Araştırma süresince insan haklarına ve araştırma etik ilkelerine sayg1 gösterilerek çalışılmıştır.

\section{BULGULAR}

Tablo 1. Kişisel Bilgilere Ait Dağılım

\begin{tabular}{|c|c|c|}
\hline Değişken & $\mathrm{N}=75$ & $\%$ \\
\hline $\begin{array}{l}\text { Yaş } \\
18-35 \text { Yaş } \\
\text { 36-60 Yaş } \\
60 \text { Yaş Üzeri }\end{array}$ & $\begin{array}{l}26 \\
30 \\
19 \\
\end{array}$ & $\begin{array}{l}34,7 \\
40,0 \\
25,3\end{array}$ \\
\hline $\begin{array}{l}\text { Cinsiyet } \\
\text { Bayan } \\
\text { Erkek }\end{array}$ & $\begin{array}{l}35 \\
40\end{array}$ & $\begin{array}{l}46,7 \\
53,3\end{array}$ \\
\hline $\begin{array}{l}\text { Boy Grupları } \\
170 \mathrm{~cm} \text {. Altı } \\
170 \mathrm{~cm} \text {. ve Üzeri } \\
\end{array}$ & $\begin{array}{l}39 \\
36 \\
\end{array}$ & $\begin{array}{l}52,0 \\
48,0 \\
\end{array}$ \\
\hline $\begin{array}{l}\text { Kilo Grupları } \\
59 \mathrm{~kg} . \text { ve Altı } \\
60-70 \mathrm{~kg} . \\
71 \mathrm{~kg} . \text { ve Üzeri }\end{array}$ & $\begin{array}{l}16 \\
27 \\
32 \\
\end{array}$ & $\begin{array}{l}21,3 \\
36,0 \\
42,7 \\
\end{array}$ \\
\hline $\begin{array}{l}\text { Ĕgitim Durumu } \\
\text { Okur-yazar Değil } \\
\text { Okur-yazar } \\
\text { İlk-Ortaokul } \\
\text { Lise } \\
\text { Üniversite }\end{array}$ & $\begin{array}{l}5 \\
3 \\
41 \\
16 \\
10\end{array}$ & $\begin{array}{l}6,7 \\
4,0 \\
54,7 \\
21,3 \\
13,3\end{array}$ \\
\hline $\begin{array}{l}\text { Meslek } \\
\text { Emekli } \\
\text { Memur } \\
\text { İşçi } \\
\text { Serbest Meslek } \\
\text { Çalışmıyor }\end{array}$ & $\begin{array}{l}9 \\
3 \\
7 \\
14 \\
42 \\
\end{array}$ & $\begin{array}{l}12,0 \\
4,0 \\
9,3 \\
18,7 \\
56,0\end{array}$ \\
\hline $\begin{array}{l}\text { Yerleşim Yeri } \\
\text { Ankara } \\
\text { Ankara-İlçe } \\
\text { Ankara-Köy/Belde } \\
\text { Ankara D1ş1 } \\
\text { Ankara D1ş1-İlçe } \\
\text { Ankara D1ş1- } \\
\text { Köy/Belde }\end{array}$ & $\begin{array}{l}22 \\
15 \\
3 \\
15 \\
6 \\
14\end{array}$ & $\begin{array}{l}29,3 \\
20,0 \\
4,0 \\
20,0 \\
8,0 \\
18,7\end{array}$ \\
\hline
\end{tabular}


Araştırmaya katılan 75 hastadan 30'unun $(\% 40,0)$ 36-60 yaş grubunda olduğu ve hastaların 35 'nin $(\% 46,7)$ bayan, 40'ının ise $(\% 53,3)$ erkek olduğu belirlenmiştir. Hastaların 41'inin $(\% 54,7)$ İlk ve Ortaokul mezunu olduğu, 42'sinin $(\% 56,0)$ çalışmadığı ve 14 'ünün $(\% 18,7)$ serbest meslekte çalıştığ

Tablo 2. Hastalıklarla İlgili Özelliklerin Dağılımı

\begin{tabular}{|c|c|c|}
\hline Değişken & $\mathrm{N}=75$ & $\%$ \\
\hline $\begin{array}{l}\text { Tedavi Görme } \\
\text { Süresi } \\
\text { 0-30 Gün } \\
\text { 1-6 Ay } \\
\text { 1-4 Y11 } \\
\text { 4 Yil Üzeri }\end{array}$ & $\begin{array}{l}29 \\
24 \\
8 \\
14\end{array}$ & $\begin{array}{l}38,6 \\
32,0 \\
10,7 \\
18,7\end{array}$ \\
\hline $\begin{array}{l}\text { Tedavi Masrafları } \\
\text { İçin Destek Alma } \\
\text { Evet* } \\
\text { Hayır }\end{array}$ & $\begin{array}{l}11 \\
64\end{array}$ & $\begin{array}{l}14,7 \\
85,3\end{array}$ \\
\hline $\begin{array}{l}\text { Hastalığa Uyum } \\
\text { Sağlama Durumu } \\
\text { Evet } \\
\text { Hayır } \\
\text { Biraz }\end{array}$ & $\begin{array}{l}35 \\
23 \\
17\end{array}$ & $\begin{array}{l}47,7 \\
30,6 \\
22,7\end{array}$ \\
\hline $\begin{array}{lr}\text { Hastalı̆̆ı Algılama } \\
\text { Durumu } \\
\text { Tedavi Edilemeyen } \\
\text { Bir Hastalık } \\
\text { Uzun Süre } & \text { Tedavi } \\
\text { Gerektiren } & \text { Bir } \\
\text { Hastalık } & \\
\text { Kolay } & \text { Tedavi } \\
\text { Edilebilen } & \text { Bir } \\
\text { Hastalık } & \\
\end{array}$ & $\begin{array}{l}5 \\
57 \\
13\end{array}$ & $\begin{array}{l}6,7 \\
76,0 \\
17,3\end{array}$ \\
\hline $\begin{array}{l}\text { Stresli Yaşam } \\
\text { Hayır } \\
\text { Evet** } \\
\text { Biraz }\end{array}$ & $\begin{array}{l}34 \\
40 \\
1\end{array}$ & $\begin{array}{l}45,3 \\
53,3 \\
1,4\end{array}$ \\
\hline $\begin{array}{l}\text { Hastalıkla İlgili } \\
\text { Psikolojik Destek } \\
\text { Alma } \\
\text { Evet, Yararı Oldu } \\
\text { Evet, Yararı Olmadı } \\
\text { Hayır, Almadım }\end{array}$ & $\begin{array}{l}7 \\
15 \\
53\end{array}$ & $\begin{array}{l}9,3 \\
20,0 \\
70,7\end{array}$ \\
\hline
\end{tabular}

*Engelli Raporu, Keçiören Vakfı, Sağlık Bakanlığı, Sosyal Hizmetler. **Maddi Sebepler, Yakının Vefat1, Duygusal Sebepler, Şiddet, Sağlık Sebepleri, Huzursuzluk, Takıntılar, Ailevi Sebepler

Hastalardan 29'unun $(\% 38,6)$ yeni tan1 aldığ 1,24 'ünün $(\% 32,0)$ 1-6 ay süredir tedavi gördüğü belirlenmiştir. Hastalardan 64 kişinin $(\% 85,3)$ tedavi masrafları için destek almadığı, 35 hastanın $(\% 47,7)$ hastalığına uyum sağladığı, 57 hastanın $(\% 76,0)$ hastalığını uzun süre tedavi gerektiren bir hastalık olarak gördüğü, 40 hastanın $(\% 53,3)$ stresli bir yaşama sahip olduğu belirlenmiştir. Hastalıkla ilgili 53 hastanın $(\% 70,7)$ psikolojik destek almadığ belirlenmiştir.

Tablo 3. Distres Termometresine Göre Stresin Ana Neden/Nedenleri

\begin{tabular}{l|l|l}
\hline Değişken* & N & \% \\
\hline Günlük Yaşam & & \\
Sorunları & 8 & 26,7 \\
Barınma & 4 & 13,2 \\
Sosyal Güvence & 8 & 26,7 \\
İş ya da Okul & 5 & 16,7 \\
Ulaşım & 5 & 16,7 \\
Çocuk Bakımı & & \\
\hline Ailevi Sorunlar & & \\
Eş & 7 & 30,4 \\
Çocuklar & 16 & 69,6 \\
\hline Duygusal Sorunlar & & \\
Üzüntü & 35 & 32,3 \\
Hüzün & 26 & 24,1 \\
Depresyon & 18 & 16,7 \\
Sinirlilik & 29 & 26,9 \\
\hline İnançla & & \\
Sorunlar & 3 & 25,0 \\
Tanrı ile İlgili & 2 & 16,7 \\
İnanç Yitimi & 7 & 58,3 \\
Diğer Sorunlar & & \\
\hline Bedensel Sorunlar & & \\
Ağrı & 21 & 7,3 \\
Bulantı & 32 & 11,1 \\
Yorgunluk & 28 & 9,8 \\
Uyku & 18 & 6,3 \\
Gezinti & 14 & 4,9 \\
& 17 & 5,9 \\
\hline
\end{tabular}




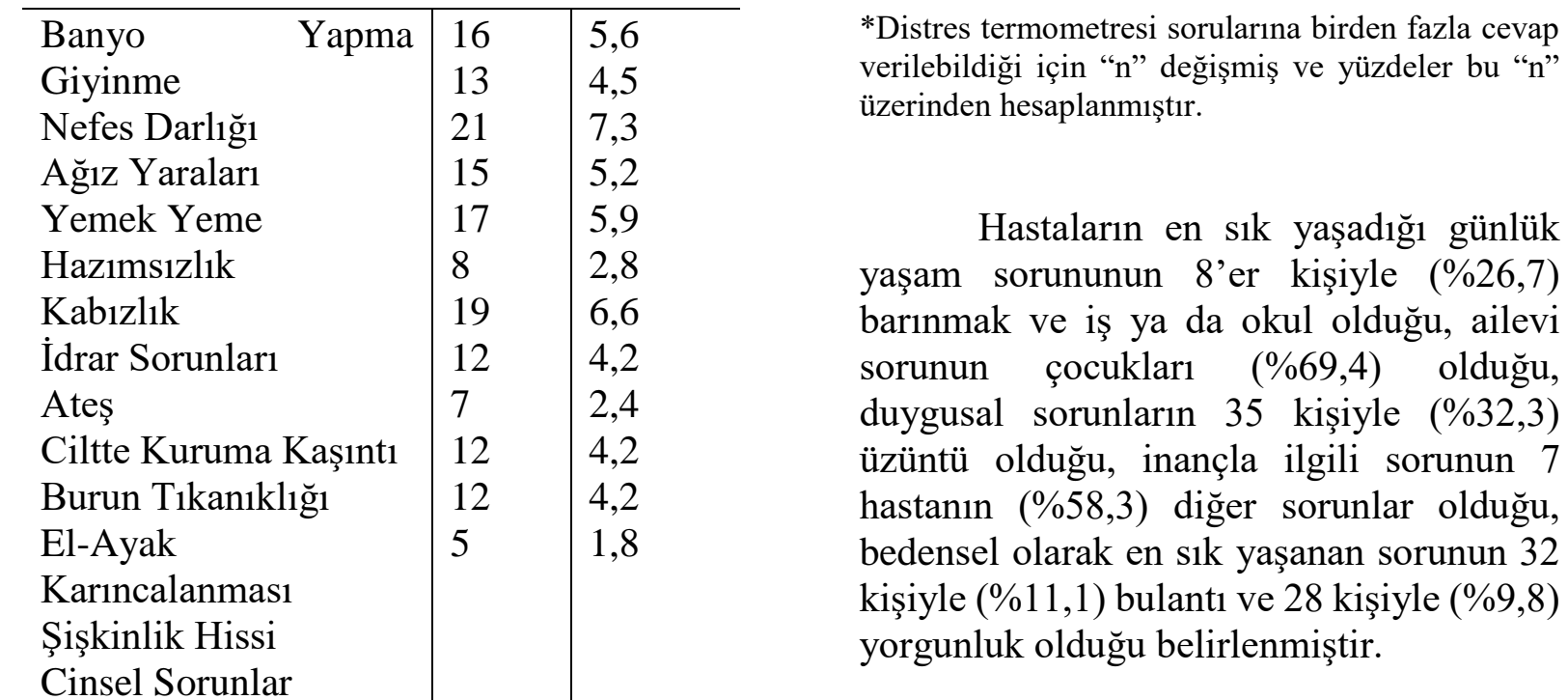

Tablo 4. Kişisel Bilgilerin HAD Ölçeği Açısından Karşılaştırılması

\begin{tabular}{|c|c|c|c|}
\hline Değişken & $\mathrm{N}=75$ & Anksiyete Alt Boyutu & Depresyon Alt Boyutu \\
\hline $\begin{array}{l}\text { Yaş } \\
18-35 \text { Yaş } \\
\text { 36-60 Yaş } \\
60 \text { Yaş Üzeri }\end{array}$ & $\begin{array}{l}26 \\
30 \\
19\end{array}$ & $\begin{array}{l}6,65 \pm 3,39 \\
6,40 \pm 4,27 \\
5,94 \pm 3,84\end{array}$ & $\begin{array}{l}7,62 \pm 3,63 \\
7,57 \pm 4,66 \\
7,21 \pm 3,51\end{array}$ \\
\hline $\begin{array}{l}\text { İstatistiksel } \\
\text { Analiz* } \\
\text { Olasılık } \\
\end{array}$ & & $\begin{array}{l}\mathrm{F}=0,183 \\
\mathrm{p}=0,833\end{array}$ & $\begin{array}{l}F=0,063 \\
p=0,939\end{array}$ \\
\hline $\begin{array}{l}\text { Cinsiyet } \\
\text { Bayan } \\
\text { Erkek }\end{array}$ & $\begin{array}{l}35 \\
40\end{array}$ & $\begin{array}{l}7,97 \pm 4,05 \\
4,98 \pm 3,04\end{array}$ & $\begin{array}{l}8,23 \pm 3,81 \\
6,85 \pm 4,09\end{array}$ \\
\hline $\begin{array}{l}\text { Ístatistiksel } \\
\text { Analiz } \\
\text { Olasılık } \\
\end{array}$ & & $\begin{array}{l}t=3,579 \\
\mathbf{p}=\mathbf{0 , 0 0 1}\end{array}$ & $\begin{array}{l}\mathrm{t}=1,502 \\
\mathrm{p}=0,137\end{array}$ \\
\hline $\begin{array}{l}\text { Eğitim Durumu } \\
\text { Okur-yazar ve Altı } \\
\text { İlk-Ortaokul } \\
\text { Lise } \\
\text { Üniversite }\end{array}$ & $\begin{array}{l}8 \\
41 \\
16 \\
10\end{array}$ & $\begin{array}{l}7,88 \pm 5,69 \\
6,24 \pm 3,54 \\
6,56 \pm 3,95 \\
5,40 \pm 3,27 \\
\end{array}$ & $\begin{array}{l}8,50 \pm 4,10 \\
7,59 \pm 4,29 \\
7,88 \pm 3,14 \\
5,70 \pm 3,89\end{array}$ \\
\hline $\begin{array}{l}\text { İstatistiksel } \\
\text { Analiz } \\
\text { Olasılık }\end{array}$ & & $\begin{array}{l}F=0,643 \\
p=0,590\end{array}$ & $\begin{array}{l}F=0,892 \\
p=0,450\end{array}$ \\
\hline $\begin{array}{l}\text { Meslek** } \\
\text { Emekli } \\
\text { İşçi } \\
\text { Serbest Meslek } \\
\text { Çalışmıyor } \\
\end{array}$ & $\begin{array}{l}9 \\
7 \\
14 \\
42 \\
\end{array}$ & $\begin{array}{l}3,89 \pm 3,76 \\
5,29 \pm 2,29 \\
6,00 \pm 3,37 \\
7,40 \pm 3,98\end{array}$ & $\begin{array}{l}4,56 \pm 3,81 \\
6,14 \pm 2,27 \\
7,50 \pm 4,20 \\
8,26 \pm 4,03 \\
\end{array}$ \\
\hline $\begin{array}{l}\text { İstatistiksel } \\
\text { Analiz } \\
\text { Olasılık } \\
\end{array}$ & & $\begin{array}{l}F=2,427 \\
p=0,056\end{array}$ & $\begin{array}{l}F=1,965 \\
p=0,109\end{array}$ \\
\hline $\begin{array}{l}\text { Medeni Durum } \\
\text { Evli }\end{array}$ & 55 & $6,35 \pm 3,56$ & $7,58 \pm 3,91$ \\
\hline
\end{tabular}




\begin{tabular}{|c|c|c|c|}
\hline $\begin{array}{l}\text { Bekar } \\
\text { Dul/Boşanmış }\end{array}$ & $\begin{array}{l}11 \\
9\end{array}$ & $\begin{array}{l}6,27 \pm 4,17 \\
6,67 \pm 5,34\end{array}$ & $\begin{array}{l}7,09 \pm 4,23 \\
7,44 \pm 4,67\end{array}$ \\
\hline $\begin{array}{l}\text { İstatistiksel } \\
\text { Analiz } \\
\text { Olasılık }\end{array}$ & & $\begin{array}{l}F=0,031 \\
p=0,970\end{array}$ & $\begin{array}{l}F=0,068 \\
p=0,934\end{array}$ \\
\hline $\begin{array}{l}\text { Çocuk Sayısı } \\
0 \\
1 \text { Çocuk } \\
2 \text { Çocuk } \\
3 \text { ve Üzeri Çocuk }\end{array}$ & $\begin{array}{l}16 \\
5 \\
18 \\
36\end{array}$ & $\begin{array}{l}6,25 \pm 4,16 \\
5,20 \pm 0,83 \\
6,50 \pm 3,98 \\
6,53 \pm 3,95\end{array}$ & $\begin{array}{l}6,44 \pm 4,03 \\
6,80 \pm 3,27 \\
7,89 \pm 3,91 \\
7,86 \pm 4,17\end{array}$ \\
\hline $\begin{array}{l}\text { İstatistiksel } \\
\text { Analiz } \\
\text { Olasılık }\end{array}$ & & $\begin{array}{l}F=0,181 \\
p=0,909\end{array}$ & $\begin{array}{l}F=0,572 \\
p=0,635\end{array}$ \\
\hline $\begin{array}{l}\text { Sigara/Alkol } \\
\text { Kullanımı } \\
\text { Hayır } \\
\text { Evet }\end{array}$ & $\begin{array}{l}54 \\
21\end{array}$ & $\begin{array}{l}6,54 \pm 4,09 \\
5,95 \pm 3,14\end{array}$ & $\begin{array}{l}7,78 \pm 4,24 \\
6,76 \pm 3,27\end{array}$ \\
\hline $\begin{array}{l}\text { Ístatistiksel } \\
\text { Analiz } \\
\text { Olasılık }\end{array}$ & & $\begin{array}{l}t=0,590 \\
p=0,557\end{array}$ & $\begin{array}{l}\mathrm{t}=0,988 \\
\mathrm{p}=0,326\end{array}$ \\
\hline
\end{tabular}

*Parametrik dağılıma sahip olan yöntemler için iki bağımsız grup karşılaştırmasında IndependentSample $t$ test ( $\mathrm{t}$ değeri); üç veya daha fazla bağımsız grup için ANOVA (F değeri) yöntemi kullanılmış ve ortalama \pm standart sapma şeklinde gösterilmiştir. **Memurların örnek sayısı (n=3) düşük olduğundan analize dahil edilmemiştir.

Hastaların cinsiyetlerine göre anksiyete alt boyutundan alınan puanlar açısından istatistiksel olarak anlamlı farklılık tespit edilmiştir $\quad(\mathrm{t}=3,579$; $\mathrm{p}=0,001)$. Bayanların anksiyete puan ortalamasinın, erkeklerin anksiyete puan ortalamasından istatistiksel olarak anlamlı düzeyde daha yüksek olduğu belirlenmiştir.Diğer değişkenler açısından HAD ölçeğinden alınan puanlar açısından farklilık yoktur $(\mathrm{p}>0,05)$.

Tablo 5. Hastalıkla İlgili Bilgilerin HAD Ölçeği Açısından Karşılaştırılması

\begin{tabular}{|c|c|c|c|}
\hline \multirow[b]{2}{*}{ Ölçekler (N=75) } & \multirow[b]{2}{*}{$\begin{array}{l}\text { Distress } \\
\text { Termometresi } \\
\end{array}$} & \multicolumn{2}{|l|}{ HAD Ölçeği } \\
\hline & & $\begin{array}{l}\text { Anksiyete Alt } \\
\text { Boyutu }\end{array}$ & $\begin{array}{ll}\text { Depresyon Alt } \\
\text { Boyutu }\end{array}$ \\
\hline $\begin{array}{l}\text { Distress } \\
\text { Termometresi }\end{array}$ & \# & $\begin{array}{l}r=0,367 \\
\mathbf{p}=\mathbf{0 , 0 0 1}\end{array}$ & $\begin{array}{l}r=0,268 \\
\mathbf{p}=\mathbf{0 , 0 2 0}\end{array}$ \\
\hline $\begin{array}{l}\text { Anksiyete } \\
\text { Alt Boyutu }\end{array}$ & $\#$ & $\#$ & $\begin{array}{l}r=0,561 \\
\mathbf{p}=\mathbf{0 , 0 0 0}\end{array}$ \\
\hline $\begin{array}{l}\text { Depresyon } \\
\text { Alt Boyutu }\end{array}$ & $\#$ & $\#$ & $\#$ \\
\hline
\end{tabular}

*Pearson korelasyon katsayısı kullanılmıştır.

Distres termometresi ile anksiyete alt boyutu arasında pozitif yönlü, zayıf derecede ve istatistiksel olarak anlamlı bir ilişki tespit edilmiştir $(\mathrm{r}=0,367 ; \mathrm{p}=0,001)$.
Distres termometresi puanı zayıf derecede arttıça, anksiyete alt boyutu da zayıf derecede artacaktır; aynı şekilde anksiyete alt boyutu zayıf derecede arttıkça, distres termometresi puanı da zayıf derecede artacaktır. 
Distres termometresi ile depresyon alt boyutu arasında pozitif yönlü, zayıf derecede ve istatistiksel olarak anlamlı bir ilişki tespit edilmiştir $(r=0,268 ; p=0,020)$. Distres termometresi puanı zayıf derecede arttıkça, depresyon alt boyutu da zayıf derecede artacaktır; aynı şekilde depresyon alt boyutu zayıf derecede arttıkça, distres termometresi puanı da zayıf derecede artacaktır.

Anksiyete alt boyutu ile depresyon alt boyutu arasinda pozitif yönlü, orta derecede ve istatistiksel olarak anlamlı bir ilişki tespit edilmiştir $(r=0,561 ; p=0,000)$. Anksiyete alt boyutu orta derecede arttıkça, depresyon alt boyutu da orta derecede artacaktır; aynı şekilde depresyon alt boyutu orta derecede arttıkça, anksiyete alt boyutu da orta derecede artacaktır.

Tablo 6. Ölçeklere İlişkin Bilgiler

\begin{tabular}{l|l|l}
\hline Ölçek & $\mathbf{N = 7 5}$ & \% \\
\hline $\begin{array}{l}\text { Distress } \\
\text { Termometresi } \\
\text { Puanı } \\
<4\end{array}$ & 23 & \\
$\geq 4$ & 52 & 69,7 \\
\hline HAD-Anksiyete & & \\
Puanı & 58 & 77,3 \\
$<10$ & 17 & 22,7 \\
$\geq 10$ & & \\
\hline $\begin{array}{l}\text { HAD-Depresyon } \\
\text { Puanı }\end{array}$ & & \\
$<7$ & 28 & 37,3 \\
$\geq 7$ & 47 & 62,7 \\
\hline
\end{tabular}

Ölçeğe ait bulguların değerlendirilmesinde 52 hastanın $(\% 69,3)$ yüksek stres $(\geq 4)$ yaşadığı, 23 hastanın $(\% 30,7)$ düşük stres $(<4)$ yaşadığı belirlenmiştir.

HAD-Anksiyete alt boyutu açısından 58 hastanın $(\% 77,3)$ anksiyete puanının 10'dan az olduğu, 17 hastanın $(\% 22,7) \quad 10$ ve üzeri olduğu belirlenmiştir.HAD-Depresyon alt boyutu açısından 28 hastanın $(\% 37,3)$ depresyon puanının 7'den az olduğu, 47 hastanın $(\% 62,7) 7$ ve üzeri olduğu belirlenmiştir.

\section{TARTIŞMA}

Araştırmamızda katılımcıların distres düzeyi, distres termometresi ölçeğine göre $\% 69,3$ 'ü 4 ve üzeri puan almış olup ve distres yaşamakta iken \%30,7'si düşük düzeyde stres yaşadığını belirtmiştir. Bultz ve Carlson (2006), kanserli hastalarda distres düzeyinin \%70'e kadar çıkabildiğini belirtmişlerdir. Avusturalya'da yapılan bir çalışmada (Musiella ve ark, 2017), tarama aracı olarak DT (Distres Termometresi) ve klinik görüşmeler kullanılmıştır. 68 katılımcının \%40'1 yüksek distres bildirmiştir. DT'de bulunan problem listesinde bütün hastalar fiziksel problem yaşadıklarını bildirmiştir ve hastaların \%72'si duygusal problemler bildirmiştir. Ülkemizde Özalp ve ark (2007) yaptığı çalışmada, kanser türü gözetmeksizin hastaların \%59,3'nün distres yaşadığı bildirilmiştir. Özbaş'ın (2008) çalışmasında ise hastaların distres yaşama durumları \% 70,4'tür.

Araştırmamızda distresin ana nedenleri distres termometresi ölçeğine göre; birinci sırada fiziksel sorunlar kısmı, ikinci sırada ise duygusal sorunlar kısmıdır. Özalp ve arkadaşlarının yaptığı çalışmada bizim araştırmamızla aynı doğrultuda en fazla sorun yaşanan alan birinci sırada fiziksel sorunlar ikinci sırada ise duygusal sorunlar olduğu bildirilmiştir. Özbaş'ın çalışmasında birinci sırada duygusal sorunlar, ikinci surada fiziksel sorunlar olduğu bildirilmiştir. Musiella ve arkadaşlarının yaptığı çalışmada ise bütün katılımcılar fiziksel sorun bildirmiștir ve hastaların \%72'si de duygusal sorunlar bildirmiştir.

\begin{tabular}{lccr}
\multicolumn{2}{r}{ Çalışmamızda en az } & sıklıkta \\
bildirilen & sorun & fiziksel & sorunlar \\
başlığındaki & cinsel & sorunlardır.
\end{tabular}


Katılımcıların sadece 5 tanesi işaretlemiştir ve $\% 1,8$ oranındadır. $\mathrm{Bu}$ oranhastaların cinsel sorunlarını paylaşmakta sıkıntı yaşadıklarını ve bu konuya değinmek istemediklerini düşündürmektedir. Benzer şekilde en az sorun bildirilen alanlardan diğeri de dini inançlar bölümüdür. Kanser tanısına sahip olmak kişinin inancını olumlu ya da olumsuz yönde etkileyebilmektedir. Hastalığın varlığı Tanrı'ya karşı öfke ve isyan duygularını uyandırabileceği ve Tanrı'dan uzaklaştırabileceği gibi tam tersi bir etki ile Tanrı ile pazarlık içinde kendini bularak iyileşme umudunu artırabilir ve böylece hasta kendini manevi olarak rahatlatabilir. Her iki durumda da olumlu veya olumsuz, hastalar Tanrı'nın rolünün büyük olduğunu düşünerek bu konuya değinmekten kaçınmış olabilir veya dini inançlarının ne yönde olduğunun sorgulanmasını hoş karşılamadıkları için yaşadıkları sıkıntıyı çok fazla bildirmek istememiş olabilirler.

Araştırmamızda, Hastane Anksiyete ve Depresyon Ölçeğine göre, hastaların \%22,7'si HAD-Anksiyete alt boyutu açısından 10 ve üzeri puana sahiptir. HADDepresyon alt boyutu açısından ise $\% 62,7$ 'sinin 7 ve üzeri puan aldığ 1 tespit edilmiştir. Hastaların klinik tanısının, evresinin, hastalığa uyum sağlama durumlarının, stresli bir yaşama sahip olma durumunun ve hastalıkla ilgili psikolojik bir destek alma durumunun HAD ölçeğinden alınan puanlar açısından istatistiksel olarak anlamlı bir farklılık yoktur. Distres termometresi ile anksiyete alt boyutu arasında pozitif yönlü, zayıf derecede ve istatistiksel olarak anlamlı bir ilişki tespit edilmiştir $(\mathrm{r}=0,367 ; \mathrm{p}=0,001)$. Distres termometresi puanı zayıf derecede arttıkça, anksiyete alt boyutu da zayif derecede artacaktır; aynı şekilde anksiyete alt boyutu zayıf derecede arttıkça, distres termometresi puanı da zayıf derecede artacaktır. Distres termometresi ile depresyon alt boyutu arasında pozitif yönlü, zayıf derecede ve istatistiksel olarak anlamlı bir ilişki tespit edilmiştir $(\mathrm{r}=0,268$; $\mathrm{p}=0,020)$. Distres termometresi puanı zayıf derecede arttıkça, depresyon alt boyutu da zayıf derecede artacaktır; aynı şekilde depresyon alt boyutu zayıf derecede arttıkça, distres termometresi puanı da zayıf derecede artacaktır.

Avusturalya'da (Cliton-McHarg ve ark,2014) hematolojik kanserli hastaların anksiyete ve depresyon prevelansını belirlemek amacıyla üç hematoloji kliniğinde ayaktan tedavi gören hastalarda HADS ölçeği kullanılarak yapılan çalışmada; 304 katılımcının \%27'sinde anksiyete, \%17'sinde depresyon bildirilmiştir. Brezilya'da yapılan bir çalışmada (Bergerot ve ark.,2015) hematolojik kanserli hastalarda distres, anksiyete ve depresyon seyrinin hastaların cinsiyetleri ve neoplazm dereceleriyle arasındaki ilişki incelenmiştir. Çalışma, 104 hematolojik kanseri hastadan oluşmuştur ve kohort yöntemiyle prospektif olarak yapılmıştır. Hastalar kemoterapi kürlerini alırken kemoterapi tedavisinin başlangıcı (T1), kemoterapi tedavisinin ortas1 (T2) ve tedavi bitimi (T3) olarak değerlendirilmiştir. Değerlendirme aracı olarak DT (Distres Termometresi) ve HAD (Hastane Anksiyete ve Depresyon ölçeği) kullanılmıştır. Yüksek derecede distres yaşayan hastaların oranı tedavinin başından sonuna kadar azalmıştır. T1'de hastaların $\% 50$ 'sinde distres, \%47,1'inde anksiyete ve \%26'sında depresyon belirtilmiştir. T2'de distres yaşayan hastaların anksiyete oranı $\% 60,8$ ve depresyon oran $1 \% 48,5$ azalmıştır. T1'den T3'e kadar toplamda \%80'e yakın azalma olmuştur. En sik fiziksel ve duygusal sorular bildirilmiştir. Cinsiyet ve fiziksel problemler arasında belirgin bir etkileşim bulunmuştur. Literatürde distres puanı ile anksiyete ve depresyon arasından anlamlı bir farklılık vardır. Distres arttıkça anksiyete ve depresyon da artmaktadir. Genellikle distres puanı yüksek olanların anksiyete puanları depresyona göre daha fazla olduğu görülmüştür. Bizim 
araştırmamızda ise distres puanı yüksek olanların depresyon oranları $(\% 62,7)$ anksiyete oranlarından $(\% 22,7)$ daha yüksek bulunmuştur.

Hastaların cinsiyetlerine göre anksiyete alt boyutundan alınan puanlar açısından istatistiksel olarak anlamlı farkl11ık tespit edilmiştir $(t=3,579$; $\mathrm{p}=0,001)$. Bayanların anksiyete puan ortalamasının, erkeklerin anksiyete puan ortalamasından istatistiksel olarak anlamlı düzeyde daha yüksek olduğu belirlenmiştir. Bulunan bu sonuç literatürle uyumludur. Literatür incelendiğinde kadınların erkeklere göre anksiyete seviyelerinin daha yüksek olduğu görülmektedir (Scheier ve ark. 2004, Pandey ve ark 2006, Wellisch ve ark 1999). Ülkemizde Tokgöz ve ark. (2008), kanser hastalarında depresyon varlığını \%22 olarak saptamış ve kadınlarda erkeklere göre daha sik olduğunu bildirmişlerdir.

\section{Araştırmaya yalnızca Dr.} Abdurrahman Yurtaslan Ankara Onkoloji Hastanesi Ayaktan Kemoterapi Ünitesi'ne kemoterapi almak için başvuran ve yetişkin hematoloji servisinde yatışı olan hastaların alınması bu araştırmanın sınırlılığıdır. $\mathrm{Bu}$ nedenle araştırmanın sonuçları yalnızca Dr. Abdurrahman Yurtaslan Ankara Onkoloji Hastanesi Ayaktan Kemoterapi Ünitesi'ne kemoterapi almak için başvuran ve yetişkin hematoloji servisinde yatışı olan hastalara yöneliktir. $\mathrm{Bu}$ araştırmadan elde edilen sonuçlar tüm kemoterapi alan kanser hastalarına genelleme yapılamaz.Bu çalışmada depresyona direkt etki edecek bir faktör olan komorbiditenin değerlendirilmemiş olması çalışmanın zayıf yönleri arasındadır.

\section{SONUÇ ve ÖNERILLER}

Çalışmamızda, hematolojik kanser tanılı ve kemoterapi tedavisi görmekte olan hastalarda distres, anksiyete ve depresyon seviyeleri değerlendirilmiştir. Sonuç olarak hastaların büyük çoğunluğu tanı anından tedavi süreci boyunca distres yaşamaktadır. Hastaların distresi artıkça anksiyete ve depresyon seviyeleri de artmaktadır. Böylece hastaların fiziksel ve emosyonel yakınmaları artmakta, tedaviye uyumu zorlaşmakta, hastane yatış süreleri artmakta, hastanın yaşam kalitesi azalmaktadır. Buna bağlı olarak hem tedavi maliyetleri hastanede uzun süre kalmaya bağlı hem de enfeksiyon riskleri de artmaktadir.

Tanı anından terminal döneme dek hastaların psikolojik sıkıntı yaşadıkları bilinmektedir. Normal sürecin dışındaki psikolojik bozulmalar sağlı ekibi tarafından gözlenmeli ve tespit edilmelidir. Kanser tanısı almış tüm hastalar için psikiyatri konsültasyonu istemenin ve liyezon boyutunun sürdürülmesinin mümkün olmadığı, kanser gibi kronik hastalıklarda beklenen doğal olarak kabul edilensüreçlerin psikolojik bozukluklardan ayırt edilmesi için konsültasyon liyezon ekibininüyelerinden konsultan liyezon psikiyatri hemşirelerinin çalışan ekibe, özelliklede hemşirelere eğitim ve destek vermesi gerekmektedir. Psikolojik sıkıntı yaşayan hastaların gözden kaçmaması, tespit edilmesi ve yönlendirilmesi açısından ve nicel olarak ölçülebilecek zaman almayan tarama ölçekleriyle hastaların rutin olarak taranması literatür 1şı̆̆ında önerilmektedir.

\section{KAYNAKÇA}

1. Andrykowski MA, Greiner CB, Altmaier EM, Burish TG, Antin JH, Gingrich R, et al. Quality of life following bone marrowtransplantation: findingsfrom a multicentrestudy. Br J Cancer 1995;71(6):1322-9.

2. Aydemir, Ö. (1997). Hastane Anksiyete ve Depresyon Ölçeği Türkçe Formunun Geçerlik ve Güvenirlik Çalışması. Türk Psikiyatri Dergisi, 8(4): 280-287.

3. Boyes A., D'este C., Carey M., Lecathelinais C., Girgis A. (2013) How does the Distress 
Thermometer compare to the Hospital Anxiety and Depression Scale for detecting possible cases of psychological morbidity among cancer survivors? SupportCareCancer 21:119-127

4. Bultz B D, Holland J C. (2006) Emotionaldistress in patientswithcancer: Thesixthvitalsign. CommunityOncology; 3 (5) 311-314.

5. Bultz B D.,Carlson E L., (2006) EmotionalDistress: TheSixthVitalSignFutureDirectionsInCancerCare. PsychoOncology 15: 93-95.

6. Çapar S. (2010) Kemoterapi Gören Kanserli Hastalarda Ağrı ile Anksiyete Ve Depresyon Arasındaki İlişkinin Değerlendirilmesi. Trakya Üniversitesi Sağlık Bilimleri Enstitüsü Hemşirelik Ana Bilim Dalı Yüksek Lisans Program1, Yüksek Lisans Tezi, Edirne.

7. Giraldi T, De Vanna M, Malagoli M et al. (2007) Mentaladaptationtocancer:

depressionandbloodplateletmonoamineoxidasea ctivity in breastcancerpatients. AnticancerResearch; May-Jun. 27 (3b).

8. Harrison JD, YoungJM , Price MA, Butow PN, Solomon MJ(2009)

Whataretheunmetsupportivecareneeds of peoplewithcancer? A systematicreview. SupportCareCancer 17:1117-1128

9. Karahan B. (2011) MultiplMiyelomlu Türk Hastalarda EORTC QLQ Kullanılarak Hayat Kalitesi Değerlendirilmesi. Trakya Üniversitesi Tıp Fakültesi İç Hastalıkları Anabilim Dalı, Uzmanlık Tezi, Edirne.

10. Karakaş S. (2007).Kanser Hastalarının Hastalığ1 Değerlendirme Biçimlerinin Anksiyete Depresyon Ve Yasam Kalitesine Etkisi. Atatürk Üniversitesi Sağlık Bilimleri Enstitüsü Psikiyatri Hemşireliği Anabilim Dalı, Yüksek Lisans Tezi, Erzurum.

11. Kulaksızoğlu IB., Olgun T., Kaçmaz Z., Akkaş S., Özkan S. (1999) Hematolojik Kanserlerde Psikiyatrik Bozuklukların Değerlendirilmesi Ve Uyum Bozuklukları. İ.Ü. İstanbul Tıp Fakültesi Psikiyatri AD. Konsültasyon Liyezon Psikiyatrisi BD., İstanbul.Türk Onkoloji Dergisi. 1999, Cilt 14, Sayı 2, Sayfa(lar) 080085

12. Nalepa P. (1996) Level of Anxiety in PatientswithLungCancer. PneumonolAlergolPol; 64: 315-22.

13. Öz F. (2004)Anksiyete ve korku. Sağlık Alanında Temel Kavramlar. İmaj İç ve Dış Ticaret AŞ, Ankara 157-179.

14. Özalp E, Cankurtaran E S, Soygür H. Geyik Özdemir P, Jacobsen P B, Screeningforpsychologicaldistress in
Turkishcancerpatients. Psycho-Oncology 2007; 16(4): 304-11.

15. Özbaş AA. (2008)Meme Kanseri Hastalarının Distres Ve Algilanan Sosyal Destek Düzeylerinin Belirlenmesi. Gazi Üniversitesi Sağlık Bilimleri Enstitüsü Hemşirelik Programı, Yüksek Lisans Tezi, Kasım; Ankara

16. Rankin NM, Barron JA, Lane LG, Mason CA, Sinclair S, Bishop JF (2011) Psychosocialoncologyservices in New South Wales. AustHealthRev 35:156-163

17. Roth A J, Kornblinth A B, Batel-Copel L, Peabody E, Scher HI, Holland J C. (1998) Rapidscreeningforpsychologicdistress in men withprostatecarcinoma: A pilot study. Cancer; 82: 1904-1908.

18. Tokgöz G.,Yaluğ İ., Yazıcı A., Uygun K., Aker T. (2008). Kanser hastalarında majör depresyon yaygınlığı ile ilişkili etmenler. Anadolu Psikiyatri Dergisi, 9:59-66.

19. Pandey M.,Sarita GP., Devi N., at al. (2006). Distress, anxietyanddepression in cancerpatientsundergroundingchemoyherapy. World J of SurgicalOncology 4:68.

20. Wellisch DK.,Hoffman A., Goldman S., at al. (1999).DepressionandAnxietysymtoms in women at high risk forbreastcancer: pilot study of a groupintervention. Am J Psychiatry 156:1644-1645

21. Scheier AM., Williams SA. (2004). Anxiety an quality of life of womenwhoreceiveradiationorchemotherapyfor breastcancer. OncologyNursing Forum 31(1):127-130.

22. Clinton-McHarg T.,Corey M., Sanson-fisher R., Tzelepis F., Bryant J., Williamson A.(2014). Anxietyanddepressionamongheamatologicalcan cerpatientsattendingtreatmentcenters:

Prevelanceandpredictors. Journal of affectivedisorders 165,176-181. Australia.

23. Musiello T.,Dixan G., O'connor M., Cock D., Miller L., Petterson A., Saunders C., Joske D., Jhonson C.(2017). A pilot study of routinescreeningfordistressby a nurseandpsychologist in an outpatientheamatologicaloncologyclinic. AppliedNursingResearch 33:15-18. Australia.

24. Volmer TC.,Wittmann M., Schweiger C., Hiddeman W.(2011). Preoccupationwithdeath as predictor of psyhologicaldistress in patientswithheamatologicalmalignancies. EuropeanJournal of CancerCare 20:403-411. Germany.

25. Bergerot DC.,Clarck KL., Nanino A., Waliany S., Busa MM., Loscalzo M. (2015). Course of 
distress, anxietyanddepression in heamatologicalcancerpatientsassociationbetwee ngenderandgrade of neoplazm. Palliativeandsupportivecare 13:115-123.Brazil.

26. Fang C.-K.,Chang M.-C., Chen P.-J., Lin C.-C., Chen G.-S., Lin J., Hsiesh R.-L., Chang Y.-F.,
Chen H.-W., Wu C.-L., Lin K.-C., Chiu YU-J., Li Y.-L. (2014). A correlationalstudy of suicidalideationwithpsychologicaldistress,

depressionanddemoralization

in patientwithcancer. Supportcarecancer 22:21653174. Taiwan 